
ФОРМУВАННЯ ЗВ'ЯЗНОГО МОВЛЕННЯ У ДІТЕЙ ЯК ПРОВІДНА ПРОБЛЕМА
СУЧАСНОЇ ДОШКІЛЬНОЇ ОСВІТИ

\title{
FORMING OF CHILDREN'S COHERENT SPEECH AS A LEADING PROBLEM OF MODERN PRESCHOOL EDUCATION
}

Статтю присвячено одній із актуальних проблем сучасної дошкільної освіти -підготовці дитини до школи. Педагогам потрібно створити міцний базис для вільного засвоєння навчальних предметів, ознайомлення з культурною спадщиною та історією своєі країни. Найважливішу роль у цьому процесі виконує мова та ії практичне застосування мовлення. Значна кількість дошкільників має труднощі під час спілкування, переказу побаченого або почутого, а творчий складник у розповіді загалом у багатьох дітей відсутній. У статті описано сучасний стан проблеми фрормування зв'язного мовлення у дітей дошкільного віку та визначено головні етапи формування такого типу мовлення (що містить діалогічне та монологічне мовлення), особливості розумової діяльності, пізнавальних, психічних і мнемонічних прочесів. Зокрема, проаналізовано сутність таких понять як зв'язне мовлення, комунікативна компетентність, дошкільний вік, творча розповідь, діалогічне та монологічне мовлення. Висвітлено лінгвістичні особливості розвитку мовлення дошкільників, основні суперечності під час фрормування зв'язного мовлення і рівні сформованості цього процесу. На основі аналізу методичної літератури автор окреслює сучасні підходи до проблеми фрормування зв'язного мовлення у дітей старшого дошкільного віку. Визначено потребу у комплексному підході до вирішення зазначеної проблеми не тільки 3 боку практики, але і у теоретичному плані. у статті підкреслено важливість формування зв'язного мовлення, починаючи саме із дошкільного віку. Основну увагу зосереджено на теоретико-методичних аспектах фрормування зв'язного мовлення для розвитку комунікативної компетентності. Йдеться про вміння та навички дитини використовувати рідну мову (фонетичні, лексичні, граматичні компоненти) відповідно до комунікативних ситуацій. Спираючись на останні дослідження у галузі дошкільної педагогіки, які визначають дошкільний вік як найсприятливіший для засвоєння нових знань, вмінь і навичок, проаналізовано, які методичні підходи позитивно впливають на формування і розвиток зв'язного мовлення у дітей. Акцентовано увагу на тісному зв'язку сорормованості мовлення, соціалізації та інтелектуального розвитку.

Ключові слова: розвиток, мовленнєвий розвиток, зв'язне мовлення, дошкільний вік, комунікативна компетентність, стандарти дошкільної освіти.

The article deals with the actual problem of the modern pre-school education: training for school. The main idea of the article is to relate language educational and socialization. Teachers should create a foundation for easier learning of school subjects, getting to know the cultural heritage and history of their country. The most important role in this process is fulfilled by the language and speech (its practical application). A significant number of children preschool age have got difficulties in process of communication, in process of retelling of seeing and hearing. As a rule, children don't have a creative component in their description. The article gives information about current state of the problem of formation of coherent speech and identifies the main stages of formation of this type of speech (dialogic and monologue speech), features of mental activity, cognitive mental and mnemonic processes. In such case, there is an urgent need for the development and correction of speech of preschool children. Text, coherent speech, communicative competence, preschool ages, dialogic and monologue speech are analyzed. In particular, the article presents the linguistic features of preschool speech development, the main contradictions of the formation of coherent speech and levels of formation of this process. The author characterizes modern methodological approaches, which are used to forming of children's coherent speech. Certain necessary in complex approach of solving this problem is not on the one hand of practice, but on the other hand of theoretical case. In the article the main attention is focused on the theoretical and methodological aspects of formation coherent speech, which are very important for $d^{*}$ evelopment of the communicative competence. The article considers the current state of this problem. It is spoken in detail about knowledge, skills, abilities which children use in this speech. Taking into consideration the fact that preschool age is very favorable for leaning, author characterizes the best ways for the appropriate organization of childrens' coherent speech. It is spoken in detail about close connection between high degree of speech competence and level of intellectual development.

Key words: development, speech development, coherent speech, preschool age, communicative competence, standards of preschool education. педагогічного університету

імені Богдана Хмельницького формується одночасно з усіма фрізичними і психічними процесами, воно потребує цілеспрямованого, методично вірного та систематичного впливу, починаючи із дошкільного віку. Звичайно, індивідуальні фрізіологічні особливості накладають певний відбиток на швидкість фрормування і темп розвитку зв'язного мовлення, проте існують вікові норми та показники сорормованості, які є індикаторами інтелектуального розвитку. У час загальної 
комп'ютеризації та широкої інформатизації суспільства рівень розвитку мовлення і комунікативних навичок дошкільнят залишає бажати кращого. Як свідчить практика, під час фрормування зв'язного мовлення у дітей все частіше виникають перешкоди, які гальмують весь навчальний процес і надалі провокують виникнення низки небажаних подій. Насамперед це неможливість адаптації у соціумі, важкість контактування 3 оточуючими, відсутність бажання спілкуватись і брати участь у спільних іграх, важкість засвоєння рідної мови, проблеми під час формування основ грамоти, низька успішність під час вивчення точних наук. Саме тому проблема фрормування зв'язного мовлення потребує більш детального вивчення із погляду на оновлені тенденції у дошкільній освіті та зміни в освіті загалом.

Аналіз останніх досліджень і публікацій. Проблема фрормування мовлення загалом і зв'язного мовлення дошкільників зокрема перебуває у центрі уваги багатьох науковців педагогічної і лінгвістичної галузі, таких як А. Арушанова, О. Бізікова, О. Білан, Л. Білоусько, А. Богуш, В. Воробйова, Л. Ворошніна, Н. Гавриш, А. Герасимова, А. Гончаренко, Л. Калмикова, О. Кононко, Ю. Кролівець, Т. Круглякова, К. Крутій, Р. Павелків, Т. Піроженко, Ю. Рібцун, Т. Ткаченко, І. Товкач, Е. Фоміна, Н. Харченко, В. Чекаліна, Л. Шадрина. Сучасні дослідження спрямовані на визначення основних суперечностей під час фрормування зв'язного мовлення і можливі шляхи їх вирішення. Традиційні підходи до навчання мови і фрормування зв'язного мовлення не дозволяють поєднати принципи класичного (дидактичного) і практико-орієнтованого (емпіричного) навчання. Розглядаючи актуальні питання психологічних особливостей і фрізичних етапів розвитку дітей дошкільного віку, ми звертаємося до наукових праць як вітчизняних, так і зарубіжних психологів, таких як В. В'юнник, А. Гресь, Т. Дуткевич, Р. Павелків, Д. Сіґел, О. Смірнова, О. Янушко. Проте, незважаючи на велику кількість і численність досліджень у цьому напрямку, не охоплюється весь діапазон зазначеної проблеми.

Виділення невирішених раніше частин загальної проблеми. Нині, у вік глобальних змін особливо важливо розуміти беззаперечне значення мови у житті дитини та її практичного застосування - мовлення. Лише досконале мовлення надає доступ до визначних надбань людської культури. Аналіз теоретичної спадщини сорери дошкільної освіти явно демонструє недоліки прийнятого підходу до фрормування мовлення у дітей. Формування комунікативних умінь, на жаль, має значний відрив від реальних умов спілкування. Сучасна дошкільна педагогіка знаходиться у пошуку таких методів навчання, які би створювали міцний взаємозв'язок між теорією і практикою. Завдання спрямовані лише на конструювання шаблонних фрраз та виразів, однак це не задовольняє один із першочергових запитів суспільства: опанування молоддю мовою у такому обсязі, щоб нею можна було не тільки контактувати на побутовому та освітньому рівнях, але і надалі встановлювати ділові та наукові відносини. Багато в чому це пов'язано з тим, що довгі роки в освіті дошкільнят увага приділялася переважно фрормуванню діалогічного (ситуативного) мовлення, і лише фрагментарно педагоги фрормували повноцінне монологічне мовлення, тоді як творча сторона мовлення взагалі залишається бездіяльною. На нашу думку, це відбувається через те, що процес формування зв'язного мовлення знаходиться на зламі двох наук: педагогіки і психології. Терміни «комунікативна компетентність», «мовленнєвий розвиток», «зв'язне мовлення» глибоко вивчаються у методиці і лінгвістиці, проте слід наголосити, що існує суттєва відмінність між розумінням цих понять. Ми вважаємо, що головне завдання сучасної дошкільної педагогіки полягає у створенні оптимальних умов для таких комунікативних вмінь, властивих зв'язному виду мовлення: сприймати, аналізувати, планувати власне висловлювання та корегувати його залежно від обставин. Окрім того, дають підстави для глибшого вивчення зазначеного процесу оновлені вимоги у новій редакції Державного стандарту дошкільної освіти, прийнятого у 2021 році, де окремою компетентністю виокремлено мовленнєву як одну із базових.

Метою роботи $€$ спроба уточнити сучасне розуміння процесу фрормування зв'язного мовлення у дітей старшого дошкільного віку як педагогічної проблеми модернізованої освіти.

Виклад основного матеріалу. За роки розбудови незалежної України в освіті визначені принципово нові тенденції і ключові пріоритети, які швидко трансорормують сутність підходів до дошкільного виховання і навчання.

Разом із безперечними прогресивними тенденціями у суспільстві спостерігаються і негативні явища: між людьми зникає живе спілкування, знижується рівень соціальної грамотності підростаючого покоління. Поряд із наявними перевагами сучасних дошкільників перед однолітками минулого (йдеться про більшу обізнаність, уміння працювати із технічними засобами навчання, швидку адаптацію у життєвих ситуаціях), неможливо оминути фрактори, які сприяють затримці дитячого розвитку.

Розвиток дитини у сучасних умовах гуманізації суспільства характеризується внутрішньою суперечливістю, насиченням парадоксами, причому майже кардинально змінюється віковий портрет сучасного дошкільника. Незважаючи на діяльну гуманізацію і гуманітаризацію всіх освітніх сорер, негативні явища знаходять яскраве віддзеркалення у поведінці дітей. Ми наведемо низку 
основних чинників, які перешкоджають цілісному психічному і психологічному розвитку дошкільника: проблеми фрізичного характеру, слабкість імперативної сорери, недостатній розвиток зв'язного мовлення, надмірна кількість інновацій, життя у віртуальному світі, діти неохоче йдуть на контакт. Діти не спроможні без планомірного педагогічного втручання досягти шкільної зрілості. Йдеться про такий рівень психічного розвитку дитини, за якого вона готова навчатись у закладі, що забезпечує початкову освіту. У такій ситуації педагоги відчувають труднощі, адже спостерігається грубість, неввічливе ставлення до інших, конолліктність, емоційна байдужість, у більшості випадків діти не здатні нормально реагувати на критику і зауваження, логічно викладати думки, аргументувати своє незадоволення або незгоду з чимось.

Проблема фрормування зв'язного мовлення (монологічного та діалогічного) як одна 3 умов успішної соціалізації недарма висвітлюється у працях кращих науковців, таких як А. Арушанова, О. Бєлобрикіна, А. Бородич, Н. Ветлугіна, $€$. Водовозова, Н. Галігузова, Л. Дубіна, О. Чеснокова, Л. Шадріна, С. Шаховська, Л. Щерба. Вони наголошують на тому, що без мовлення процес соціалізації неможливий, а без зв'язного мовлення неможливе успішне навчання у школі.

В останні десятиліття взагалі все частіше помічається зміна наслідувального рефлексу, тобто копіювальне відтворення почутого за дорослим: у сучасної дитини переважає рефлекс «свободи» - самостійне будування стратегії поведінки [3]. За свідченням відомої дослідниці дитячої психології Т. Дуткевич, чільне місце серед фракторів психічного розвитку дитини посідає спілкування, передусім у колі родини, потім - із однолітками та іншими людьми. Науковець акцентує увагу на тому, що без справжнього живого спілкування неможливим $є$ формування, а згодом і розвиток особливих психічних фрункцій у дитини, гальмується процес індивідуального самовизначення [4, с. 79]. Ефективність спілкування визначається рівнем мовленнєвої компетенції людини, яка прямо залежить від рівня розвитку їі мовної особистості, комунікативних вмінь і навичок. В оновленому Базовому стандарті дошкільної освіти ми знаходимо таке визначення цього поняття: «це здатність дитини продукувати свої звернення, думки, враження тощо у будь-яких фрормах мовленнєвого висловлювання за допомогою вербальних і невербальних засобів. Мовленнєва компетентність об'єднує фонетичний, лексичний, граматичний, діалогічний, монологічний складники та засвідчує їх взаємозалежність і взаємозумовленість» $[1$, c. 18]. Мовлення як практичне застосування мови $€$ не тільки вербальним засобом вираження думок, воно є невід'ємною частиною багатокомпонентної структури нашого інтелекту. За нормального біологічного розвитку для інтелекту дитини старшого дошкільного віку характерні гнучкість, креативність, швидкість і самостійність розумових дій. Щодо оволодіння мовленням, то дитина рухається від частини до цілого, від одного слова до цілого речення, від речення до логічно поєднаного тексту. Поняття «зв'язне мовлення» (воно є складником мовленнєвої компетентності) відноситься як до діалогічної, так і до монологічної форм мовлення. Кожна з них має свої особливості. Під час формування монологічного мовлення відбувається дещо нерівнозначне спілкування (одноосібне мовлення, котре інші пасивно сприймають); під час діалогу спілкування $€$ рівноцінним (відбувається бесіда, активний обмін інформацією). У нашому буденному житті діалогічне мовлення здебільшого не планується та носить спонтанний характер. Хоча діалог і $є$ складною фрормою соціальної взаємодії між людьми, до такого типу зв'язного мовлення висувається значно менше обмежень, ніж до організації розширеного монологічного висловлювання.

Керуючись програмою розвитку дитини від народження до шести років «я у Світі» (інваріантна частина), ми зазначимо, що поняття «зв'язне мовлення» містить не тільки фронетичний, лінгвістичний, граматичний аспекти, але і навички мовленнєвої культури: не перебивати співрозмовника та уважно його слухати, встановлювати зоровий контакт, говорити розбірливо, не поспішаючи, спокійним і лагідним тоном [7, с. 355]. Зупинімося докладніше на основних вимогах до мовленнєвих вмінь, знань і навичок дитини шести років: логічно і послідовно будувати розповідь; уникнення постійних повторів, довгих пауз; дотримання наміченої структури розповіді залежно від типу висловлювання; помічати цікаві сюжети; знаходити помилки у мовленні своїх товаришів; самостійно складати сюжетні розповіді з опорою на картину або серію картин; переказувати основні моменті твору близько до тексту; за аналогією вміти складати оповідання (на запропоновану педагогом тему або відповідно до літературного твору чи сюжетного зображення), враховуючи місце, час дії, головних і другорядних діючих осіб [6, с. 188]. Якісні показники зв'язного мовлення, його лексико-семантичне поле, відсутність мовленнєвих стереотипів, лексичне наповнення вказує на якість загальних розумових здібностей, логічних зв'язків, мислительних операцій, здатність до розуміння конотації. Слід відмітити, що комунікативна компетентність як одна із головних компетентностей розвивається під час мовлення, і тільки регулярна активізація цього процесу дає змогу коригувати психічні процеси під час сенситивного розвитку мовлення. Ми згодні $з$ думкою Р. Павелкова, який зазначає, що всі психічні фрункції розвиваються за безпосереднього впливу мовлення, що стимулює і поглиблює 
розвиток. Зрозуміло, що фрункції мовлення і комунікативні фрорми у дитини старшого дошкільного віку надзвичайно швидко вдосконалюються порівняно із середнім і молодшим дошкільним віком. Порівняно із раннім дитинством словник дошкільника збільшується утричі: у 3 роки дитина засвоює приблизно 1200-1500 слів; у 4 роки - 2000; у 5 років 2500-3000; у 6-7 років - 4000-4500 слів [5]. Зі свого боку, закономірний лексичний розвиток забезпечує повноту розуміння значення слів. Існують певні умови для розвитку комунікативно-мовленнєвої компетенції, насамперед це потреба висловлюватися, наявність змісту, інфрормації, тобто того, про що потрібно сказати. Результати наукових досліджень А. Богуш і Н. Гавриш підкреслюють орієнтацію лінгводидактики на застосування активних способів навчання, оскільки саме вони сприяють не простому відтворенню мовленнєвих одиниць, а насамперед осмисленому продукуванню власного висловлювання [2, с. 183]. Механізм породження зв'язного мовлення лінійно пов'язаний із мотивацією. Відтак можна стверджувати, що у роботі із розвитку зв'язного мовлення у дітей важливо створювати такі ситуації, в яких вони б усвідомлювали користь від своїх розповідей, переказів. Чим більше матеріалу для осмислення надасть педагог, чим повніше, багатше, цінніше буде цей матеріал, тим набагато змістовнішими будуть висловлювання дитини, тобто дитина буде озброєна потрібними знаннями. Важливо не просто давати дітям «зразки мови», а стимулювати мовленнєве висловлювання, постійно надихати на творчість і заохочувати до самовираження себе через мовлення.

Висновки. Як відомо, єдиної загальноприйнятої методики фрормування зв'язного мовлення для дітей дошкільного віку не існує, але одностайною $€$ думка, відповідно до якої ми повинні розглядати індивідуальний підхід у поєднанні 3 інноваційними технологіями як дієвий напрямок у фрормуванні зв'язного мовлення у дітей. Підсумовуючи вищезазначене, ми відзначимо, що орієнтація на розумові здібності, рівень зацікавленості під час навчання, збагачення предметної діяльності дітей старшого дошкільного віку у цьому процесі, врахування специфічних особливостей цього вікового періоду дозволяє досягти позитивних результатів в освітньому процесі загалом.

\section{БІБЛІОГРАФІЧНИЙ СПИСОК:}

1. Базовий компонент дошкільної освіти від 12 січня 2021 р. Київ: 2021. 37 с.

2. Богуш А. М., Гавриш Н. В. Дошкільна лінгводидактика: Теорія і методика навчання дітей рідної мови в дошкільних навчальних закладах: підручник. Київ: Видавничий Дім «Слово», 2015. 704 с.

3. Горбунова Н. В., Калімуллина О. А. Портрет дошкільника: ретроспектива, тенденції. Проблеми сучасної педагогічної освіти. 2019. № 63-1. URL: https://cyberleninka.ru/article/n/portret-doshkolnikaretrospektiva-tendentsii (дата звернення: 10.06.2021).

4. Дуткевич Т. В. Дитяча психологія: навч. посіб. Київ: Центр учбової літератури, 2012. 424 с.

5. Павелків Р. В., Ципигайло О. П. Дитяча психологія. Академвидав 2008, 431 c. URL: https://westudents. com.ua/knigi/498-dityacha-psihologya-pavelkv-rv.html (дата звернення: 11.06.2021)

6. Плохій 3. П., Кулачківська С. Є., Ладивір С. О. Малятко: програма виховання дітей дошкільного віку. Київ, 2001. 287 с.

7. Аксьонова О. П. та ін. Я у Світі. Програма розвитку дитини від народження до шести років; за наук. кер. О.Л. Кононко. Київ: ТОВ «МЦФЕР-Україна», 2019. 488 c 